\title{
Birger Andersen*
}

\section{Dictionary Grammars}

\begin{abstract}
Based on a number of general proposals for the structure and contents of dictionary grammars, put forward by Mugdan (Mugdan (1989), and reviews of existing dictionary grammars in a number of dictionaries, the article makes proposals for the structure and contents of a dictionary grammar for a particular type of dictionary, namely a bilingual LSP dictionary for $\mathrm{L}_{2}$ production.
\end{abstract}

\section{Dictionaries, Grammars and Dictionary Grammars}

Before a discussion of the nature and possible functions of dictionary grammars it might be useful to separate the two things 'dictionary' and 'grammar' to look at them individually before we let them come together again. The purpose should be to determine - in grammatical terms - what a dictionary is or should be capable of doing and what a grammar - understood here as an account of the grammar of a particular language - is or should be capable of doing. Herbst (1989) has the following to say on the subject:

'Whereas a grammar (in the sense of a grammar book) contains all the generalizable features of a language, the dictionary contains its idiosyncracies. Syntactic rules such as the use of the tenses or aspects in English are largely independent of individual words and thus fall under the domain of a grammar, but this does not apply to all grammatical phenomena: It is part of the grammatical description of a language such as English, for example to state that a distinction between count and uncount nouns has to be made, to identify the different types of complementation verbs can take, or, in the field of morphology, to list the various morphological possibilities for forming the past tense of a verb etc. However, one would not expect the treatment of such phe-

\footnotetext{
* Birger Andersen

Aarhus School of Business, University of Aarhus

Fuglesangsallé 4

DK-8210 Aarhus V

ba@asb.dk
}

Hermes - Journal of Language and Communication Studies no 38-2007 
nomena in a grammar to be comprehensive in the sense that it would provide information on, for example, all the complementation possibilities of every verb or list all the uncount nouns of the language etc. The place for this type of grammatical information which cannot be generalized is the dictionary.'

(Herbst 1989:94)

Almost the same view is echoed in Jackson (1985):

'A Grammar is concerned with the general rules affecting the classes of items in a language. A Dictionary is concerned with the operation of individual lexical items.'

(Jackson 1985:53)

Somewhat simplifying, we may say that the principal task of the grammar is to generalize (although also very often at the same time exemplifying), whereas the principal task - with respect to grammatical information - of the dictionary is to indvidualize.

Why is it then that we sometimes want to bring the two together in a dictionary grammar? What is it that a dictionary grammar is capable of which neither a dictionary nor a grammar is capable of on their own?

Mugdan (1989) defines a dictionary grammar in the following terms:

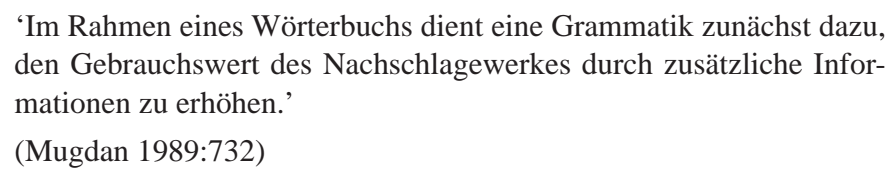

What these 'zusätzliche Informationen’ might consist of is exemplified by:

(a) the bringing together of linguistic elements which are torn apart by the alphabetical ordering (of the dictionary entries) - such as numerals and word formation elements which can be given a systematic treatment in a dictionary grammar;

(b) information which is not related to single lexical elements such as pronunciation, punctuation, inflection, use of tenses, concord, etc.

There is thus a sort of 'division of labour' between the dictionary proper and the dictionary grammar. This division of labour can be illustrated by means of the following examples, in which grammatical information 
in the dictionary entries is given in the form of codes (or in some other economical way), which describe (aspects of) the grammatical properties of the entry word. All examples relate to English.

(a) Verb complementation patterns can be fully described - at least for production purposes - by codes indicating the formal categories in which the complements are realised. A good example of this is the verb grammar codes used in OALD6. An alternative are the pattern illustrations for verb complementation used in LDOCE4. All that is required of the dictionary grammar is an explanation of the codes. ${ }^{1}$

(b) The possibility of collective nouns to be combined with the verb in either the singular or the plural can be indicated by a code (in the relevant dictionary entries) such as the one used in OALD6, where such nouns are marked (sing./pl. v.) However, the conditions under which the singular or the plural should be chosen are difficult to state in any economical form (for example as codes), and an account of this is therefore better left to the dictionary grammar.

(c) It is generally accepted by grammarians that English nouns are as a general rule countable. However, uncountable nouns do exist, of course, and an economical way of stating this in the dictionary entries would be to mark the uncountable nouns as such and leave the countable nouns unmarked. However, it would be very difficult indeed to invent codes to indicate that some determiners combine only with uncountable nouns (much, little, enough), some combine only with countable nouns ( $a$, each, every), while some combine with both (the, some). This kind of grammatical information must be given in a dictionary grammar.

Now, to return to Mugdan's definition of the concept of dictionary grammar, it is a rather general and abstract characterization of what a dictionary grammar is. It does not, for example, tell us what form such information should have. In the following, we will attempt to operationalize this very general characterization by illustrating the concept with

1 This does not exclude the possibility of describing in a dictionary grammar for a bilingual dictionary systematic differences between complementation patterns in the two languages. We shall return later to the aspect of contrastiveness in dictionary grammars for bilingual dictionaries. 
a number of different types of dictionary grammars. The ultimate aim is to set up a number of requirements for a dictionary grammar for a particular type of dictionary: a bilingual LSP dictionary for $\mathrm{L}_{2}$ production.

\section{Contents of Dictionary Grammars}

Mugdan (1989) contains first of all a list of linguistic structures, elements and phenomena which may be part of a dictionary grammar. It is worth noting, first of all, that according to Mugdan, not all dictionary grammars must include everything from his list, because

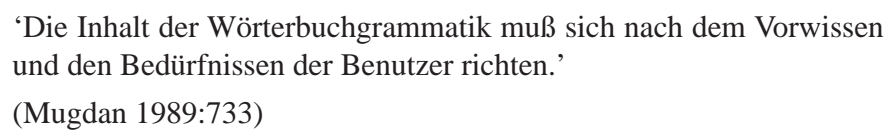

It is also worth noting that Mugdan's list of items to include in a dictionary grammar contains elements which by many grammarians would not be considered grammatical, but rather semantic or pragmatic. However, in a lexicographic context, this should not worry us too much. What counts in a lexicographic context is giving the dictionary users what they need without worrying about discussions of lines of demarcation between the disciplines of linguistics.

Mugdan's list ranges from phonetics/phonology (for example regional pronunciation differences), over orthography (for example punctuation), word classes, inflection, morphology/word formation (for example lists of word formation elements), syntax (for example sentence types, obligatory/facultative clause constituents, constituent order) to semantics, pragmatics, language varieties and language history (for example development of vocabulary).

At various points, Mugdan points to the division of labour between the dictionary (in the individual dictionary entries in the word list) and the dictionary grammar. About morphology he points out for example that affixes and other word formation elements can alternatively be lemmatized in the word list, while the dictionary grammar deals with their productivity, that is their generalizable aspect.

He also points to the dictionary grammar as the place where various coding systems used in the dictionary entries are explained, for example the transcription system for pronunciation, syntactic codes for com- 
plements of verbs and other word classes, codes for language varieties (dialects and sociolects), etc. etc.

This establishes at least one type of relationship between the dictionary entries and the dictionary grammar, but as we shall see later, other types of relationship between the two dictionary components can be established as well.

\section{Structure of Dictionary Grammars}

Mugdan now goes on to making suggestions for other aspects of the dictionary grammar - firstly the structure of the dictionary grammar (Mugdan 1989:743). Here he distinguishes between two main types, the thematically structured dictionary grammar and the alphabetically structured dictionary grammar, which is in fact a grammatical dictionary or encyclopedia. We find an example of alphabetically structured dictionary grammar (called 'Lexikon der deutschen Sprachlehre') in Wahrig-DW7.

This is a rather large dictionary grammar of almost 100 pages, supplemented by a number of inflection tables for nouns and verbs. The large size of the grammar is partly due to the fact that it is thematically rather comprehensive, ranging from phonetics ('Konsonant') over punctuation ('Gedankenstrich') and syntax ('Futur') to semantics ('Konnotation') and pragmatics ('Briefschreiben')

An alternative to the alphabetically structured dictionary grammar as a separate component of the dictionary is the sytem used in the Collins COBUILD monolingual dictionaries (for example COBUILD4), where grammatical terms are lemmatized. The amount of grammatical information we get by means of the lemmatized grammatical terms is very limited, however. If we want to know something about 'past tense', we must look under 'tense' where we are told the following:

'The tense of a verb group is its form, which usually shows whether you are referring to past, present, or future time.'

(COBUILD4 1493)

The dictionary user looking for information about the meaning and the use of 'past tense' is indeed ill served by this dictonary entry. For this reason, we would perhaps say that COBUILD4 does not have a diction- 
ary grammar at all, and never intended to have one. ${ }^{2}$ It is also obvious that this alternative is not an option for LSP dictionaries.

Alphabetically structured dictionary grammars, such as the one in Wahrig-DW, have been criticized for being difficult to access. We cannot be sure what entry to look for in order to access the information we need. This is partly due to differences in grammatical terminology used in different grammatical models of description. It is also a problem that related items of information are placed in different entries, which necessitates a frequent use of references between entries. For these reasons, most lexicographers recommend the thematically structured dictionary grammar.

Thematically structured dictionary grammars are normally structured on the basis of word class. An example is the dictionary grammar found i OALD6, which is structured on the basis of the grammatical codes used in the dictionary entries to indicate the grammatical properties of the entry word.

Here is an example taken from the section describing the meaning of the codes for verb complementation:

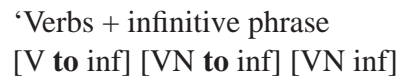

By and large there is nothing objectionable about these explanations of codes used in the dictionary entries. The complementation possibilities are indicated in the codes by means of the formal categories in which

2 We should note, however, that the COBUILD dictionaries do give much valuable grammatical information, namely in the form of the grammtical codes given in a special column alongside the dictionary entries. 
the complements can be realised - here for example infinitive clauses. For anybody using the dictionary for production purposes, these codes and their explanation provide all the information required.

However, this dictionary grammar wants to go one step further and explain also the clause-functional relationships between the complements, for example the clause-functional differences between the following two sentences:

(1) Can you persuade Sheila to chair the meeting?

(2) I expected her to pass her driving test first time.

That there are clause-functional differences between the two sentences can be demonstrated by topicalisation:

(1a) *What I could persuade was Sheila to chair the meeting.

(2a) What I expected was her to pass her driving test first time.

This shows that her to pass her driving test first time is a constituent, in this case the direct object, and it also shows that Shiela and to chair the meeting are two separate constituents with Sheila as the direct object; this is also what OALD6's dictionary grammar tells us. But this seems to be the end of the story. We are not told what clause function to chair the meeting has, neither are we told what clause-functional relationships obtain between the constituents in her to pass her driving test first time.

Now, we cannot demand of any dictionary grammar that is is all-inclusive. There must be somewhere a limit to the depth of description. But in this case there seem to be ambitions about a more comprehensive description of grammatical structures that just explanations of grammatical codes, and in this case the place at which the functional description stops seems to be quite arbitrary.

Another possibility for a thematically structured dictionary grammar is simply to imitate the kind of grammatical description we find in grammar textbooks. Such a dictionary grammar is found in COBUILDSD2, which is an example of what is normally called a traditional reference grammar.

This dictionary grammar, which is more than 200 pages long, has chapters on basic sentence structure and types of sentences, on word 
classes, different types of clauses and on modals. As can be seen, it limits itself to what is traditionally understood by grammar.

The dictionary grammar in COBUILD-SD2 is a relatively isolated component of the dictionary. There are no links to other components such as the word list, for example in the form of explanations of grammatical codes, since the dictionary entries have only a very limited amount of codes to describe the grammatical properties of the entry words. This lack of connections between the dictionary grammar and other components of the dictionary makes it difficult to imagine that it will be used to any appreciable extent in connection with the use of other components of the dictionary. For that reason, it seems reasonable to question whether we can call it a dictionary grammar at all.

The dictionary grammars we have dealt with so far have all been components of monolingual dictionaries, mainly learners' dictionaries. It is also a common feature for them that we do not find very enlightening instructions for how to use them. The same can be said of the dictionary grammar fragments we find in a number of English monolingual learner's dictionaries. They are characterized by including in their dictionary grammars only a very limited selection of the linguistic elements in Mugdan's list. Figure 1 gives a survey of what three English monolingual learner's dictionaries have to offer in this respect.

Figure 1: Grammar in three English monolingual learner's dictionaries

\begin{tabular}{|l|l|l|}
\hline CALD1 & LDOCE4 & MEDAL1 \\
\hline Grammar: & Articles & Numbers \\
Relative clauses & Modal verbs & Phrasal verbs \\
Phrasal verbs & Phrasal verbs & Academic English \\
Determiners & Idioms & Metaphor \\
Modal verbs & Writing (letter writing) & Computer words \\
& Linking ideas & Pragmatics \\
Pronunciation: & Pragmatics & Spoken discourse \\
Homographs & Collocation & Sensitivity (offensive \\
Homophones & & words/expressions) \\
& & British and American \\
Letter writing & & English \\
Regular inflections & & Business English \\
Punctuation & & Word formation \\
Varieties of English & & \\
\hline
\end{tabular}


There is agreement among these dictionaries that phrasal verbs deserve a place in their dictionary grammar fragments, but otherwise there is wide variation in their selection of the grammatical, semantic and pragmatic phenomena they include.

\section{Choice of Grammatical Model of Description}

Mugdan now moves on to a discussion of choice of grammatical model of description for dictionary grammars. In this respect, he has a clear preference for the model of description of traditional grammar such as the one we find for example for English in what we call the Quirk family of grammars (Quirk et al. (1985), Greenbaum (1991) and others). The preference is thus for a grammatical model of description operating with the traditional clause functions - subject, direct object, etc. - and the traditional word classes - noun, verb, adjective, etc. This choice is based on the fact that the traditional models of grammatical description are the ones dominating in both mother-tongue and foreign-language teaching almost everywhere.

In some languages, such as for example Danish, there is a chocie between a Danish grammatical terminology and a grammatical terminology derived from Latin. What should be chosen for a particular dictionary grammar must be decided on the basis of what is known about the grammatical knowledge of the intended dictionary users. What counts in the first place for Mugdan is consistency with respect to definitions and terminology.

\section{Dictionary Grammars and Types of Dictionaries}

Mugdan finally addresses the very central issue of the relationship between dictionary grammars and types of dictionary.

\subsection{General Monolingual Dictionaries for Native Speakers}

The first type of dictionary he discusses is the general monolingual dictionary for native speakers. The normal thing for this type of dictionary is that there is no dictionary grammar as such but only inflection tables. However, many of these dictionaries also include orthographic and punctuation rules. This applies for example to the Danish dictionary PNDO. However, for such dictionaries, Mugdan (1989:745) recom- 
mends a 'Kurzgrammatik' without specifying what the contents should be apart from a description of the terminology and model of description used in the dictionary.

\subsection{General Monolingual Learner's Dictionaries}

The next type of dictionary discussed by Mugdan is the general monolingual learner's dictionary. For these, Mugdan recommends a dictionary grammar which treats grammatical issues which are notoriously difficult for the users of the dictionary. Taking into account that the users are non-native speakers, this seems odd, since there is wide variation between which grammatical areas of for example English that are notoriously difficult for learners with different mother tongues. The consequence would seem to be that publishers of monolingual learner's dictionaries such as Oxford Advanced Learner's Dictionary would have to publish a large number of different editions, each with a dictionary grammar adapted to learners with different mother tongues, or at least a large number of separate dictionary grammars to accompany the dictionary. This would hardly seem to be commercially viable.

\subsection{Bilingual Dictionaries}

Before we look at what Mugdan has to say about dictionary grammars for bilingual dictionaries, we might keep in mind what Bergenholtz (1995) - in a general review of grammar in bilingual dictionaries - has to say specifically about dictionary grammars in bilingual dictionaries:

'I de fleste tilfælde mangler der en eksplicit ordbogsgrammatik, som forklarer de mest grundlæggende dele af det pågældende sprogs grammatik, hvortil der kan henvises fra de enkelte ordbogsartikler. Og også når en sådan ordbogsgrammatik findes, bliver der ikke altid gjort brug af den, så der opstår modsætninger og uklarheder mellem ordbogsgrammatik og grammatiske informationer i de enkelte ordbogsartikler.'

['In most cases, there is no explicit dictionary grammar, which explains the most fundamental aspects of the grammar of the language in question, to which references can be made from the individual entries. And in those cases where there is such a dictionary grammar, it is not always made use of, giving rise to inconsistencies and confusions 
between the dictionary grammar and grammatical information in the individual dictionary entries.']

(Bergenholtz 1995:6)

Such was the situation with respect to dictionary grammars in bilingual dictionaries in 1995, and the situation has not changed much since then.

For bilingual dictionaries Mugdan recommends that as a minimum they include a dictionary grammar for each language, written in the other language. These grammars should be adapted to the function of the dictionary, such that for example for a dictionary whose function is to aid translation and which is used by users of the dictionary with both mother tongues, there should be a grammar to assist reception and a grammar to assist production. Mugdan also opens up the possibility for a mother-tongue dictionary grammar for dictionary users who have not received adequate training in the grammar of their mother tongue.

An example of a dictionary (or actually two dictionaries) which fulfil Mugdan's requirements are the two dictionaries RMA and RAM. These two dictionaries go even a step further, each including no less than four dictionary grammars: A Madagascan grammar in Madagascan, a Madagascan grammar in German, a German grammar in Madagascan, and a German grammar in German.

However, the most important point about these dictionaries is perhaps not the number of grammars they contain, but the fact that there are explicit references from individual dictionary entries to relevant sections of the grammar, both the Madagascan and the German grammar. An example is:

\section{'mampi- Verbalmorphem, das zur Bildung kausaler Ver- ben dient, z.B. ma mpi-teny $\rightarrow$ $\rightarrow 1.5 .2$ '}

(RMA 366)

$\S 1.5 .2$ in the Madagascan grammar describes, among other things, the prefixes used to form causative verbs.

We saw previously how explanations in the dictionary grammar of grammatical codes used in the dictionary entries established a link between these two components of the dictionary. The system of explicit 
references from dictionary entries to sections of the dictionary grammars in RMA and RAM is a further way of establishing such links.

Mugdan (1989) is not very specific with respect to suggestions for the contents of dictionary grammars for bilingual dictionaries. All he has to say is the following:

\footnotetext{
'Aus der Festlegung der Benutzergruppe ergeben sich auch Folgerungen für den Inhalt der Grammatik: im allgemeinen wird man die Prioritäten nach kontrastiven Gesichtspunkten setzen.'

(Mugdan 1989:746 - my emphasis)
}

The important point here is of course Mugdan's recommendation that dictionary grammars for bilingual dictionaries should be contrastive without specifying further what this means in concrete terms for such dictionary grammars.

However, the aspect of contrastiveness deserves a more thorough discussion since it is by no means unambiguous.

\section{Contrastive Dictionary Grammars}

In Bergenholtz \& Pedersen (1994), we find first the following general recommendation for the inclusion of a dictionary grammar in - presumably - general-language dictionaries:

'[...] we would advocate the incorporation of a separate dictionary grammar that gives an overall survey of the grammar of the language in question, for consultation as a small grammatical handbook in its own right at the same time as it functions as the systematic background of all grammatical information included in the dictionary microstructure.'

(Bergenholtz \& Pedersen 1994: 353)

For active bilingual LSP dictionaries, however, they recommend a contrastively organized grammar (a differential grammar in their terms):

'We thus consider information on differential grammar particularly called for, i.e. information on such grammatical features as are characterstic of the LSP variety in question, in so far as they distinguish this variety from general language.'

(Bergenholtz \& Pedersen 1994:354) 
Bergenholtz \& Pedersen do not state explicitly whether "the LSP variety in question" is the $\mathrm{L}_{1} \mathrm{LSP}$ variety or the $\mathrm{L}_{2}$ LSP variety, but we will assume that it is the $\mathrm{L}_{2} \mathrm{LSP}$ variety.

The contrastive aspect here thus refers to differences between $\mathrm{L}_{2}$ general-language grammar and the grammar of a particular $\mathrm{L}_{2} \mathrm{LSP}$ variety (or rather grammatical peculiarities of a particular $\mathrm{L}_{2} \mathrm{LSP}$ variety). These differences are exemplified by socalled register-specific rules for technical English, which, according to Bergenholtz \& Pedersen, shows (among other things) a marked preference for heavily premodified nominal phrases, the passive voice and non-finite verbs and a limited use af articles and personal pronouns.

However, other contrasts can be established as well in a dictionary grammar for a bilingual LSP dictionary. First and foremost, we may give a contrastive account of the general-language grammars of the two languages of the bilingual dictionary. Since Bergenholtz \& Pedersen seem to take the view that the lexicographer can always assume that dictionary users of LSP dictionaries have sufficient knowledge of general-language grammar, this is not an issue for them.

If such an account were to be incorporated into a dictionary grammar, it would desribe grammatical phenomena, which are systematically different in the two languages. The point of departure of the description is always $\mathrm{L}_{1}$ grammatical phenomena. The following example, which is the 'Contents' for chapter three of the dictionary grammar found in EDE (and here translated into English), illustrates this:

\footnotetext{
'3. The grammar of the verb

3.1 Danish monotransitive/English intransitive + monotransitive verbs

3.2 Danish verbs with at-clause/English verbs without that-clause

3.3 Danish verbs with at-clause/English verbs with that-clause + indirect object

3.4 Danish ditransitive verbs/English verbs with that-clause + prepositional phrase

3.5 Danish monotransitive verbs/English phrasal or prepositional verbs

3.6 Danish preposition + at-clause

3.7 Danish preposition + infinitive'

(EDE 621)
} 
Secondly, we may give a contrastive account of the grammatical peculiarities of the $L_{1} L S P$ variety and the $L_{2}$ LSP variety. If we take the grammatical peculiarities for technical English as stated by Bergenholtz and Pedersen and contrast them with technical Danish for example, we would presumably find that technical Danish is also characterized for example by a marked preference for the passive voice, while the frequency of non-finite verb forms will be lower than in English and instead of heavily premodified noun phrases we will find a high frequency of compound nouns. There may even be cases in which a grammatical peculiarity of the LSP variety in one language is non-existent in the other language. Nielsen \& Sørensen (1998) describes - among other things - a Danish syntactic construction, which is highly frequent in legal texts, but non-existent in English. In the construction, the head of a noun phrase is premodified by a combination of a prepositional phrase and a participle or an adjective. The construction is emplified in (3):

(3) de i denne lov omhandlede opfindelser

[the - in - this - act-referred to - inventions]

the inventions referred to in this act

According to Nielsen \& Sørensen, no Danish-English legal translation dictionary gives any suggestions with respect to translation strategies in cases like these, but it is clear that such cases are obvious condidates for inclusion in a dictionary grammar for such dictionaries.

Finally, we may give a contrastive account of $\mathrm{L}_{1}$ general-language grammar and the grammatical peculiarities of the $\mathrm{L}_{1}$ LSP variety in question, corresponding to the contrastive account of the $\mathrm{L}_{2}$ generallanguage grammar and the peculiarities of the $\mathrm{L}_{2}$ LSP variety.

The decision about what to include in a dictionary grammar for a specific dictionary, and how to structure and present what is included, will depend, first of all, on the function of the dictionary, that is whether it is for text reception, text production, translation or some other function. ${ }^{3}$ Secondly, the decision must be based on the grammatical knowledge of the intended users of the dictionary. In the following section, we will attempt to set up a number of concrete proposals for the contents

3 For functions of dictionaries in general, see Bergenholtz \& Nielsen (2006). For functions of LSP dictionaries, see Bergenholtz \& Tarp (1995). 
and structure of a dictionary grammar for a specific dictionary with a specific function: A bilingual LSP dictionary for $\mathrm{L}_{2}$ production.

\section{Proposals for a Concrete Dictionary Grammar}

Based on the foregoing discussion of existing dictionary grammars, we may now set up a proposal for the contents of a dictionary grammar for a concrete dictionary, namely a bilingual LSP dictionary for $\mathrm{L}_{2}$ production. We will set up first the minimum elements for the contents of such a dictionary grammar, but supplement these with possible elements that may be included in the dictionary grammar.

The minimum elements include:

1. Explanation of the purpose and use of the dictionary grammar (a user's manual).

2. Account of the grammatical model of description and the grammatical terminology used.

3. Explanation of the grammatical codes used in the dictionary entries.

4. Contrastive account of differences between (selected) general-language syntactic structures, with $\mathrm{L}_{1}$ as point of departure.

5. Contrastive account of possible register- and/or genre-specific differences in frequencies of occurrence of (selected) syntactic structures, with $\mathrm{L}_{1}$ as point of departure.

6. Explicit references from the dictionary entries to relevant sections of the dictionary grammar, whenever relevant.

According to the general linguistic knowledge of the dictionary users and their knowledge of the $\mathrm{L}_{2}$ LSP variety in question, the dictionary grammar may also include the following elements:

7. General syntactic description of the $\mathrm{L}_{2}$ LSP variety covered by the dictionary.

8. Relevant aspects of the general-language characteristics of $L_{2}$ (cases, tenses, punctuation, language varieties, etc.)

9. Contrastive account of genre conventions in the relevant LSP variety apart from the purely syntactic (for example pragmatic and structural). 
The foregoing discussion of existing grammars should have given the arguments for the inclusion of most of the elements in the dictionary grammar, but a few comments might be in place.

First, why do we want to include a contrastive accunt of differences between general-language syntactic structures (element 4)? After all, we might assume that the intended users of an LSP dictionary, including LSP students, may already possess sufficient knowledge of both $\mathrm{L}_{1}$ and $\mathrm{L}_{2}$ general-language syntax in order for them to produce adequate $\mathrm{L}_{2}$ LSP texts. However, it is the contrastive arrangement of the dictionary grammar in this respect which is the important point here. The systematic contrasting of $\mathrm{L}_{1}$ syntactic structures with equivalent $\mathrm{L}_{2}$ syntactic structures will be extremely valuable for not only LSP students but also more experienced writers (and translators) in their production of $\mathrm{L}_{2}$ LSP texts.

The degree to which elements 7 and 9 should be included will depend on the intended dictionary users. LSP students will need more here than more experienced dictionary users, who will to some extent be familiar with the syntactic, pragmatic, structural, etc. characteristics of the relevant $\mathrm{L}_{2}$ LSP texts.

As far as element 8 is concerned, it should of course be included only where we can assume only the most basic $\mathrm{L}_{2}$ grammatical knowledge on the part of the intended dictionary users.

\section{References}

\section{I: Dictionaries}

CALD1 = Gillard, P. (ed.) 2003: Cambridge Advanced Learner's Dictionary. Cambridge University Press.

COBUILD4 = Sinclair, J.(ed.) 2003: Collins COBUILD Advanced Learner's English Dictionary. 4th ed. HarperCollins Publishers.

COBUILD-SD2 = Sinclair, J. (ed.) 2002: Collins COBUILD New Student's Dictionary. 2nd ed. HarperCollins Publishers.

EDE = Andersen, B., Balsgart, K. \& Tarp, S. 2006: Engelsk Dansk Erhvervsordbog. Gyldendal.

LDOCE4 = Summers, D. (ed.) 2003: Longman Dictionary of Contemporary English. 4th ed. Pearson Education Limited.

MEDAL1 = Rundell, M. (ed.) 2002: Macmillan English Dictionary for Advanced Learners. Macmillan Education. 
OALD6 = Hornby, A.S. and Wehmeier, S. (eds.) 2000: Oxford Advanced Learner's Dictionary of Current English. 6th ed. Oxford University Press.

PNDO = Becker-Christensen, C. (ed.) 1996: Politikens Store Nye Nudansk Ordbog. Politikens Forlag A/S.

RAM = Bergenholtz, H. (ed.) 1994: Rakibolana Alema-Malagasy. Hrsg. von Henning Bergenholtz in Zusammenarbeit mit Suzy Rajaonarivo, Rolande Ramasomanana, Baovola Radanielina und Jürgen Richter-Johanningmeier, Eckehart Olszowski, Volker Zeiss unter Mitarbeit von Sabine Stegemann, Hantanirina Ranaivoson, Raymonde Ravaololomboahangy und Mavotiana Razafiarivony. Tsipika.

RMA = Bergenholtz, H. (ed.) 1991: Rakibolana Malagasy-Alema. Nataon'i Henning Bergenholtz miaraka amin'i Suzy Rajaonarivo, Rolande Ramasomanana, Baovola Radanielina sy Jürgen Richter-Johanningmeier, Eckehart Olszowski sy Volker Zeiss ary Hantanirina Ranaivoson, Nicole Rasoarimanana, Raymonde Ravololomboahangy sy Mavotiana Razafiarivony. Leximal.

WAHRIG-DW7 = Wahrig, G. 2000: Deutsches Wörterbuch. Neu herausgegeben von Dr. Renate Wahrig-Burfeind. 7. Auflage. Bertelsmann Lexikon Institut.

\section{II: Other literature}

Bergenholtz, H. 1995: Grammatik i bilingvale ordbøger. In LexcoNordica 2. 5-18.

Bergenholtz, H. \& Nielsen, S. 2006: Subject-field components as integrated parts of LSP dictionaries. In Terminology 12.2. 281-303.

Bergenholtz, H. \& Pedersen, J. 1994: Grammar in bilingual LSP dictionaries, with a special view to technical English. In Schaeder, B. and Bergenholtz, H. (eds..) Fachlexikographie. Fachwissen und seine Repräsentation in Wörterbüchern. Gunther Narr Verlag. 351-383.

Bergenholtz, H. \& Tarp, S. 1995: Manual of Specialised Lexicography: The Preparation of Specialized Dictionaries. John Benjamins Publishing Company.

Greenbaum, S. 1991: An Introduction to English Grammar. Longman.

Herbst, T. 1989: Grammar in Dictionaries. In Tickoo, M.L. (ed.) Learners' Dictionaries. State of the Art. (Anthology Series 23.) Southeast Asian Ministers of Education Organisation. Singapore: RELC. 94-111.

Jackson, H. 1985: Grammar in the Dictionary. In Ilson, R. (ed.), Dictionaries, Lexicography and Language Learning. ELT Documents 120. Pergamon Press (in association with The British Council). 53-59.

Mugdan, J. 1989: Grundzüge der Konzeption einer Wörterbuchgrammatik. In Hausmann, F.J., Reichmann, O., Wiegand, H.E. \& Zgusta, L. (eds.): Wörterbücher. Dictionaries. Dictionnaires. Ein internationales Handbuch zur Lexikographie. An International Encyclopedia of Lexicography. Encyclopédie internationale de lexicographie. Vol I. Walter de Gruyter. 732-749.

Nielsen, S. \& Sørensen, R. 1998: Juridiske oversættelsesordbøger. In LexicoNordica 5. $129-148$. 
136

Quirk, R., Greenbaum, S., Leech, G. and Svartvik, J. 1985: A Comprehensive Grammar of the English Language. Longman. 